\title{
Identification of sentence types for writing skill in teacher education
}

\author{
Mehmet Demirezen ${ }^{\mathrm{a}} *$ iD \\ ${ }^{a}$ Ufuk University, Ankara, Turkey
}

\section{APA Citation:}

Demirezen, M. (2019). Identification of sentence types for writing skill in teacher education. Journal of Language and Linguistic Studies, 15(1), 98-110.

\begin{abstract}
This research aims to explore the ability of English majors to identify the four basic types of sentences. English language has four types of sentences, each kind of sentence for different kinds of messages. Sentences are combinations of words that express complete thoughts. Sentences are basic building blocks of writing and communication; therefore, breaking our ideas into sentences is essential for clear communication. In traditional grammar, the four basic types of sentence structures are the simple sentence, the compound sentence, the complex sentence, and the compound-complex sentence, whose identification by the non-native student teachers may be problematic. It's crucial that English majors recognize word order and sentence types in English to improve their academic writing skills, and hence the identification of four types of sentences by English majors is a must. In this research 35 English majors with low intermediate background were given a pretest of 20 questions in terms of a multiple-choice test to measure their initial success at the beginning. After 6 hours of intense sentence structure recognition studies, they were given the same pretest, after al elapse of 15 days, as the posttest to determine their final success on the discrimination of simple, compound, complex sentences, and compound-complex sentences from each other. After the collection of data from pre-test and post-tests, the data were analyzed by SPSS 21 . It was discovered that while pre-test's was $23 \%$, the mean score of the post-test came up to be $56 \%$, the percentage of ascent being \% 23 .
\end{abstract}

(C) 2019 JLLS and the Authors - Published by JLLS.

Keywords: Complex sentence; compound sentence; compound-complex sentences; simple sentence

\section{Introduction}

"There is increasing attention to the role of sentences and grammar in both typical and atypical readers and writers" (Scott and Balthazar, 2015:18). In English grammar, the term sentence structure indicates the arrangement of words, phrases, and clauses in a sentence (Teshner and Evans, 2007; Alexander, 2003; Greenbaum and Nelson, 2002). The grammatical meaning of a sentence is dependent on this structural organization, which is also called syntax or syntactic structure (Burton Roberts, 2016:164). How sentences are constructed and how different types of sentences are formed and accepted as two functional musts in teaching writing. Learning about the different types of sentences and punctuation in teaching writing help the students to become better writers by enabling them to convey

*Corresponding author. Tel.: +90 3125867455

E-mail address: mehmet.demirezen@ufuk.edu.tr 
various types of information and emotion in their writing. To achieve this aim, the identification of sentence types, as simple-compound-complex and compound-complex (Appelt, 1992: 123; BurtonRoberts, 2016: I64; Radford, 2008: 7; Brandon and Brandon, 2010: 61-62; Verspoor \& Sauter 2000), is highly necessary for Academic excellence; otherwise, using one type of a sentence type makes the writing boring, uninteresting, and confusing.

Needless to say, students' discriminative knowledge on four types of sentences along with the role punctuation plays a significant function in determining and creating those different sentence types both in comprehension and writing skills. Different types of sentences are made up of different combinations of types of clauses, each of which requires different degrees of discrimination skill that depends on discriminative knowledge. It is the discriminative knowledge that feeds the writing knowledge development in terms of discriminative skill advancement that opens the doors to struggling writers via teaching writing strategies.

Through the power of discrimination skill on sentence types, students can vary the tone of their writing assignments and express a variety of thoughts and emotions by helping students form and strengthen the foundation for strong writing skills in paragraph, composition, and essay writing. Then, identification of four sentence types provides learners with the framework for the clear written expression of their ideas. Breaking the ideas into four types of sentences, being transparent in terms of grammatically formed phrases and clauses is essential for clear communication. If not, serious problems of sentence recognition arise, as indicated by Demirezen (2012:143), who pointed out that "It must be noted that dangling modifiers, which are misplaced modifiers in phrases and sentences, are potential ambiguity carriers".

\subsection{Literature review}

The Literature on the recognition of sentence types is scanty. Syntactic deficits affect an individual's reading, comprehension, and writing performance. It has been discovered that sentences with syntactic difficulties pose to the learners of any age and profession serious recognition difficulties. For example, syntactic difficulties give even to children specific impairment of certain recognition difficulties. "Syntactic difficulties are a core feature in the profiles of children with specific language impairment (SLI)" (Scott and Balthazar, 2015: 18-30). "We also know these children are at high risk for long-lasting reading difficulties (Catts, Bridges, Little, \& Tomblin, 2008: 1569-1579).

In the field of educating English majors, in a study by Demirezen (2013: 560-566) on intermediate students of English majors at the Department of Language Education in a state in university in Ankara titled "The recognition of extended simple sentences as a problem" indicated serious problems of recognition. Similarly, in a research (Demirezen, 2012: 135-146), on intermediate students of English majors at the Department of Language Education in a state in university in Ankara titled An analysis of the problem-causing structures of simple sentences for Turkish university students, it was discovered that expanded simple sentences from the beginning, middle, and of the sentences by means of phrases in forms of double and triple components confuse the students, who perceive them as not simple sentences but as compound, complex, add compound-complex sentences. In this respect, "paraphrasing to be particularly helpful for identifying student misunderstandings in longer sentences, which often involve multiple forms of complexity and challenging concepts or vocabulary simultaneously (Scott and Balthazar, 2015:11; Scott \& Balthazar, 2010; Gillam, Fargo, \& Robertson, 2009).

In another research made by Demirezen (2012b) titled "The recognition of difficulty of extended compound sentences for Turkish first year English language education students", 55 English major participants at the Faculty of Education at Hacettepe University, Ankara, Turkey. In this research, a pretest and posttest were implemented. The 55 participants were given a pretest questionnaire including 
25 questions with 5 alternatives on simple, compound, complex, and compound-complex and were asked to identify the compound sentence as the correct alternative. After the administration of the pretest, 6 hours of intensive teaching and practices by means of different types on the recognition on four types of sentences were made. A special PowerPoint on the topic including several types of exercises was prepared and was handed to the participants for study in their leisure. After an elapse of three weeks, the same pretest was administrated to the participants. Pretest conclusions denoted that the participants had problems in identifying the compound sentences and especially the extended compound sentences. Treatment procedure, the use of six hours extra teaching by power-point and extra homework designs, has considerably contributed to the perception of extended compound sentences by the participants. The results of the research go in line with the deductions of Scott and Balthazar (2015: 4), who indicated that extended sentences "increase complexity and render sentences harder to comprehend and produce."

A research conducted titled "An analysis of recognition of extended compound sentences" by Güneş (2013: 25-37) on 35 participants who were first grade ELT students of Dicle University, Turkey. She implemented a pre-test of 30 questions with multiple to the participants and she also implemented the same pretest as a posttest after 2-week remedial teaching. Güneş (2013) concluded that recognizing extended compound sentences is not a problem for the first grade ELT students of Dicle University, Turkey. $70 \%$ score may be accepted as an average success for the participants, whose rate does not correlate to B1 level. Therefore, Güneş (2013) conducted a treatment of two weeks, which promoted the rate of recognition of extended compound sentences from $70 \%$ to $93 \%$, which is a highly desirable result for academic excellence, after the classroom instruction. So, effective recognition, comprehension and writing of sentences requires further recognition and practice of sentence types (Demirezen, 2012b) and training is required to form a cohesive whole from the sentences (Demirezen, 2012b; Güneş, 2013; Bosher, 1998; Leki and Carson, 1995; Bhatia, 1990; Johns, 1990).

Samanc1 (2011: 7-19) analyzed simple and compound sentences titled "Teaching simple and compound sentences with computers at intermediate level" to improve intermediate students' sentence knowledge (simple and compound sentences) by using computer-based activities by utilizing the MacroMedia Breeze Presenter Program. She conducted in the second term of 2011-2012 academic years at TOBB University of Economics and Technology, English Preparatory School, Ankara, Turkey. To conduct this study, the researcher used pretest and posttest technique to observe the effects of computer-based activities. The research included two groups: control group and experimental group. The sample of the study included 80 preparatory students as 40 control group students and 40 experimental group students. ( $\mathrm{n}=80 ; 41$ males and 39 females). As a result of the study, there has been a significant difference between control group and experimental group in favor of the latter, as indicated by the following charts in Table 1 and Table 2 :

Table 1. T-Test Paired Samples for Pre-test and Post-test Results of Experimental Group

\begin{tabular}{lcccc}
\hline & & M & SD & Std. Error Mean \\
\hline \multirow{2}{*}{ Pair I } & Experimental Pre-test & 15.8250 & 7.5715 & 1.19716 \\
& & & & .38645 \\
\hline
\end{tabular}


Table 2. T-Test Paired Samples for Pre-test and Post-test Results of Control Group

\begin{tabular}{lcccr}
\hline & & M & SD & Std. Error Mean \\
\hline Pair I & Control Pre-test & 12.8250 & 4.93646 & .78052 \\
& & & & .86049 \\
\hline
\end{tabular}

(Adapted from Samanc1, 2011: 16-18).

Samanc1 (2011) concluded that the use of computer, and specifically computer-based activities designed with MacroMedia Breeze Presenter Program has a benefit to the students of English in the sense of sentence structure.

\subsection{Research questions}

This research is a pilot study whose purpose was to analyze students' recognition of types of English sentences whether they are simple, complex, compound or compound-complex sentences by low intermediate English majors.

1. Specifically, the following research questions were addressed:

2. Is there a meaningful difference between the pre-test and post-test?

3. What is the order of success in simple sentences (1-5)?

4. What is the order of success in compound sentences (6-10)?

5 . What is the order of success in complex sentences (11-15)?

6. What is the order of success in compound-complex sentences (16-20)?

7. What is the ascending order of all sentences in terms of success?

8. Do the participants need a treatment?

\section{Method}

\subsection{Sample / Participants}

This research was conducted at Ufuk University in the 2017 Fall Term, in the English Language Education Department in Ankara.

In this research, thirty-five (35) first year students, who took the test on purposeful voluntary basis, were included. The age of the participants varied from 18 to $28 ; 30$ of them were females while 5 of them were males. The participants came from almost all types of government high schools and therefore they formed a heterogeneous group. Moreover, the University Entrance exam scores of the participants were not in the rank of the first 150, 000 students.

\subsection{Instrument(s)}

The design of this research was a pre-test/post-test design. A written test including 20 questions with multiple choices was used as the instrument of this research. There were five alternatives for each question that included simple, compound, complex and compound complex sentences. 


\subsection{Data collection procedures}

The research was made during the teaching of the course titled ELT 108 Advance Writing and Reading, which was taught by the researcher. Before starting to implement the tests, the 20 questions of the pretest were checked by a committee of 3 colleagues at the Department of English Language Education in Ufuk University of Ankara and the questions that might be unsuitable were changed.

Before the students started to answer the questions, they were informed about the research and it was indicated that the identities and answers of the students would be kept confidential. They were asked to write their full names on the test. The aim was to be able to compare pre-test and post-test afterwards. The students were given 30 minutes to answer the test.

After implementing the pre-test, the students were exposed to an intense two-week - six hourstreatment teaching. During the teaching process, all types of sentences were practiced. Components of sentences were figured out via parsing in which the sentences were broken down into its parts and identification of separate phrases, clauses, and sentences. The view is that students can become better writers by identifying the sentence types. Effective writers use a variety of types of sentences to keep the reader interested in what they are reading. The first step in identifying a sentence is to figure out its components. This can be done by breaking the sentence down into its parts and identification of separate phrases, clauses, and sentences, which help them to write confidently.

After the pretest, a PowerPoint presentation was also prepared on topic of this research and was handed to the participants by the researcher. Two YouTube video shows from the internet were used for practice purposes. In addition, since there was a time limit of 6 hours, the participants were assigned to study on two more YouTube videos from the Internet in their leisure.

After an elapse of two weeks, the pretest including the same 20 questions was implemented to the participants. The data derived from pretest and posttest was analyzed in a quantitative way by using SPSS 21.

\section{Results and Discussion}

This section aims to present the findings of this research as scientific results. The collected data from pretest and posttest were analyzed by SPSS 21 . According to data analysis, the general findings in line with the research questions are presented below.

1. Is there a meaningful difference between the pre-test and post-test?

In order to find out whether there is a statistically significant difference between pre-test and posttest scores of the participants' a Paired Samples T-Test was conducted assuming that the case for this sample group requires parametric tests in use. Accordingly, there was a statistically significant difference between pre-test scores $(\mathrm{M}=2.357, \mathrm{SD}=1.03)$, and post-test scores $(\mathrm{M}=5.671, \mathrm{SD}=1.7985) \mathrm{t}$ (34) $=9.05, \mathrm{p}=.000$ as can be seen in the Table 3 below:

Table 3. Paired Samples T-Test

\begin{tabular}{ccccc}
\hline & & M & SD & Std. Error Mean \\
\hline Pair I & Post-Test - Pre-Test & .33143 & .21662 & .03662 \\
\hline
\end{tabular}

As mentioned, the mean score of the posttest was $56 \%$ while pretest was $23 \%$. Therefore, the percentage of ascent came up to be as $23 \%$. 
2. What is the order of success in simple sentences (1-5)?

Table 4. Descriptive Statistics for Pre-test (simple sentences)

\begin{tabular}{ccccccc}
\hline & $\mathrm{N}$ & Min & Max & M & SD & $\%$ \\
\hline Item 4 & 35 & 0 & 1 & .1429 & .35504 & 14 \\
Item 2 & 35 & 0 & 1 & .1714 & .38239 & 17 \\
Item 3 & 35 & 0 & 1 & .1714 & .38239 & 17 \\
Item 5 & 35 & 0 & 1 & .2000 & .40584 & 20 \\
Item 1 & 35 & 0 & 1 & .5143 & .50709 & 51 \\
Valid N (listwise) & 35 & & & & &
\end{tabular}

The table 4 displays the pre-test scores of all simple sentences in ascending order. As one can understand, the highest score belongs to Item $1(\mathrm{M}=.5143)$ and the lowest score belongs to Item $4(\mathrm{M}$ $=.1429$ ).

Table 5. Descriptive Statistics for Post-test (simple sentences)

\begin{tabular}{ccccccc}
\hline & $\mathrm{N}$ & Min & Max & M & SD & $\%$ \\
\hline Item 4 & 35 & 0 & 1 & .6000 & .49705 & 60 \\
Item 2 & 35 & 0 & 1 & .6286 & .49024 & 62 \\
Item 5 & 35 & 0 & 1 & .6571 & .48159 & 65 \\
Item 3 & 35 & 0 & 1 & .7429 & .44344 & 74 \\
Item 1 & 35 & 0 & 1 & .9429 & .23550 & 94 \\
Valid N (listwise) & 35 & & & & &
\end{tabular}

Table 5 above displays the post-test scores for all simple sentences in ascending form. As one can understand from the table, the highest score belongs to Item $1(\mathrm{M}=.9429)$. Besides, Item 3 follows it with a mean score of .7429 and it is followed by Item $5(\mathrm{M}=.6571)$ and Item $2(\mathrm{M}=.6286)$. The lowest scores are of Item $4(\mathrm{M}=.6000)$.

3. What is the order of success in compound sentences (6-10)?

Table 6. Descriptive Statistics for Pre-test (compound sentences)

\begin{tabular}{ccccccc}
\hline & $\mathrm{N}$ & Min & Max & M & SD & $\%$ \\
\hline Item 10 & 35 & 0 & 1 & .1143 & .32280 & 11 \\
Item 6 & 35 & 0 & 1 & .2571 & .44344 & 25 \\
Item 7 & 35 & 0 & 1 & .2571 & .44344 & 25 \\
Item 8 & 35 & 0 & 1 & .3429 & .48159 & 34 \\
Item 9 & 35 & 0 & 1 & .4000 & .49705 & 40 \\
Valid N (listwise) & 35 & & & & &
\end{tabular}

Table 6 displays the pre-test scores of all compound sentences in ascending order. The highest score belongs to Item $9(\mathrm{M}=.4000)$ and the lowest score belongs to Item $10(\mathrm{M}=.1143)$. 
Table 7. Descriptive Statistics for Post-test (compound sentences)

\begin{tabular}{ccccccc}
\hline & $\mathrm{N}$ & Min & Max & M & SD & $\%$ \\
\hline Item 10 & 35 & 0 & 1 & .1429 & .35504 & 14 \\
Item 7 & 35 & 0 & 1 & .4571 & .50543 & 45 \\
Item 9 & 35 & 0 & 1 & .5143 & .50709 & 51 \\
Item 8 & 35 & 0 & 1 & .7429 & .44344 & 74 \\
Item 6 & 35 & 0 & 1 & .7714 & .42604 & 77 \\
Valid N (listwise) & 35 & & & & &
\end{tabular}

The Table 7 above displays the scores of compound sentences in ascending order. The highest score belongs to Item $6(\mathrm{M}=.7714)$, followed by Item $8(\mathrm{M}=.7429)$, and Item $9(.5143)$, and Item 7 $(\mathrm{M}=.4571)$. The lowest score belongs to Item $10(\mathrm{M}=.1429)$. Besides, it can be obviously seen that the scores of simple sentences are higher than compound ones.

4. What is the order of success in complex sentences (11-15)?

Table 8. Descriptive Statistics for Pre-test (complex sentences)

\begin{tabular}{ccccccc}
\hline & $\mathrm{N}$ & Min & Max & M & SD & $\%$ \\
\hline Item 14 & 35 & 0 & 1 & .0857 & .28403 & 8 \\
Item 13 & 35 & 0 & 1 & .1429 & .35504 & 14 \\
Item 12 & 35 & 0 & 1 & .1714 & .38239 & 17 \\
Item 15 & 35 & 0 & 1 & .2571 & .44344 & 25 \\
Item 11 & 35 & 0 & 1 & .3429 & .48159 & 34 \\
Valid N (listwise) & 35 & & & & &
\end{tabular}

The table 8 displays the pre-test scores of all complex sentences in ascending order. As one can understand, the highest score belongs to Item $11(\mathrm{M}=.3429)$ and the lowest score belongs to Item 14 $(\mathrm{M}=.0857)$.

Table 9. Descriptive Statistics for Post-test (complex sentences)

\begin{tabular}{ccccccc}
\hline & $\mathrm{N}$ & Min & Max & M & SD & $\%$ \\
\hline Item 15 & 35 & 0 & 1 & .4286 & .50210 & 42 \\
Item 11 & 35 & 0 & 1 & .4571 & .50543 & 45 \\
Item 13 & 35 & 0 & 1 & .4857 & .50709 & 48 \\
Item 12 & 35 & 0 & 1 & .5143 & .50709 & 51 \\
Item 14 & 35 & 0 & 1 & .5143 & .50709 & 51 \\
Valid N (listwise) & 35 & & & & &
\end{tabular}

Table 9 above displays the post-test scores for all complex sentences in ascending form. As one can understand from the table, the highest scores belong to Item $14(\mathrm{M}=.5143)$ and Item $12(\mathrm{M}=.5143)$. Besides, Item 13 follows it with a mean score of .4857 and it is followed by Item $11(\mathrm{M}=.4571)$. The lowest score is of Item $15(\mathrm{M}=.4286)$. 
5. What is the order of success in compound-complex sentences (16-20)?

Table 10. Descriptive Statistics for Pre-test (compound-complex sentences)

\begin{tabular}{ccccccc}
\hline & N & Min & Max & M & SD & $\%$ \\
\hline Item 17 & 35 & 0 & 1 & .1714 & .38239 & 17 \\
Item 20 & 35 & 0 & 1 & .1714 & .38239 & 17 \\
Item 16 & 35 & 0 & 1 & .1714 & .38239 & 17 \\
Item 19 & 35 & 0 & 1 & .1714 & .38239 & 17 \\
Item 18 & 35 & 0 & 1 & .4571 & .50543 & 45 \\
Valid N (listwise) & 35 & & & & &
\end{tabular}

The table 10 displays the pre-test scores of all complex sentences in ascending order. As one can understand, the highest score belongs to Item $18(\mathrm{M}=.4571)$ and the lowest scores belong to Item 17 $(\mathrm{M}=.1714)$, Item $20(\mathrm{M}=.1714)$, Item $16(\mathrm{M}=.1714)$, and Item $19(\mathrm{M}=.1714)$.

Table 11. Descriptive Statistics for Post-test (compound-complex sentences)

\begin{tabular}{ccccccc}
\hline & N & Min & Max & M & SD & $\%$ \\
\hline Item 17 & 35 & 0 & 1 & .2000 & .40584 & 20 \\
Item 16 & 35 & 0 & 1 & .4571 & .50543 & 45 \\
Item 20 & 35 & 0 & 1 & .6571 & .48159 & 65 \\
Item 19 & 35 & 0 & 1 & .6857 & .47101 & 68 \\
Item 18 & 35 & 0 & 1 & .7429 & .44344 & 74 \\
Valid N (listwise) & 35 & & & & &
\end{tabular}

Table 11 given above displays the post-test scores for all complex sentences in ascending form. As one can understand from the table, the highest scores belong to Item $18(\mathrm{M}=.7429)$ and Item $19(\mathrm{M}=$ $.6857)$. Besides, Item 20 follows it with a mean score of .6571 and it is followed by Item $16(\mathrm{M}=.4571)$. The lowest score is of Item $17(\mathrm{M}=.2000)$.

6. What is the ascending order of all sentences in terms of success?

Table 12. Descriptive Statistics for Post-test

\begin{tabular}{|c|c|c|c|c|c|c|}
\hline & $\mathrm{N}$ & Min & Max & $\mathrm{M}$ & SD & $\%$ \\
\hline Item 10 & 35 & 0 & 1 & .1429 & .35504 & 14 \\
\hline Item 17 & 35 & 0 & 1 & .2000 & .40584 & 20 \\
\hline Item 15 & 35 & 0 & 1 & .4286 & .50210 & 42 \\
\hline Item 16 & 35 & 0 & 1 & .4571 & .50543 & 45 \\
\hline Item 11 & 35 & 0 & 1 & .4571 & .50543 & 45 \\
\hline Item 7 & 35 & 0 & 1 & .4571 & .50543 & 45 \\
\hline Item 13 & 35 & 0 & 1 & .4857 & .50709 & 48 \\
\hline Item 9 & 35 & 0 & 1 & .5143 & .50709 & 51 \\
\hline Item 14 & 35 & 0 & 1 & .5143 & .50709 & 51 \\
\hline
\end{tabular}




\begin{tabular}{lllllll} 
Item 12 & 35 & 0 & 1 & .5143 & .50709 & 51 \\
Item 4 & 35 & 0 & 1 & .6000 & .49705 & 60 \\
Item 2 & 35 & 0 & 1 & .6286 & .49024 & 62 \\
Item 20 & 35 & 0 & 1 & .6571 & .48159 & 65 \\
Item 5 & 35 & 0 & 1 & .6571 & .48159 & 65 \\
Item 19 & 35 & 0 & 1 & .6857 & .47101 & 68 \\
Item 18 & 35 & 0 & 1 & .7429 & .44344 & 74 \\
Item 8 & 35 & 0 & 1 & .7429 & .44344 & 74 \\
Item 3 & 35 & 0 & 1 & .7429 & .44344 & 74 \\
Item 6 & 35 & 0 & 1 & .7714 & .42604 & 77 \\
Item 1 & 35 & 0 & 1 & .9429 & .23550 & 94 \\
Valid N & 35 & & & & & \\
(listwise) & & & & & & \\
\hline
\end{tabular}

Table 12 includes all the sentences in ascending order. The highest score belongs to Item $1(\mathrm{M}=$ $.9429)$ and the lowest score belongs to Item $10(\mathrm{M}=.1429)$. The other items also demonstrated in the table.

7. Do the participants need a treatment?

When the scores for both pre-and posttests are taken into consideration, it can be understood that the participants' scores for posttest are higher than those of pretest. However, a treatment is needed, when the sampling group has been taken into consideration. As the participants are enrolled in an English Language Teaching program, the mean score of $56 \%$ success is inadequate. In addition, there are some items which have low scores such as Item 10, 17, 15, 16, 11 and 7. They can be the focus point for treatment, too. Besides, further research can be done on the reasons why the participants had low scores on these specific items.

\section{Conclusions}

This research was based on identification of 4 types of English sentences whether they were simple, compound, complex, or compound-complex sentences. As a conclusion of the research, the mean score of the pretest was $23 \%$ while posttest came up to be $56 \%$, the percentage of ascent being $\% 23$. It is apparent that 6-hour intense practice was not enough although the students get the general idea of what is being said. Thus, even though there are many other topics to handle in the program, a treatment of three more hours will be necessary to spare to teach and apply the same test.

Lower-intermediate students usually have difficulties because their English level is around A2-B1, especially pertaining to the recognition of sentence types. In addition, it must be noted that there are serious difficulties and handicaps in doing research with lower-intermediate groups of participants, whose background on English grammar is not appropriately developed.

\section{Limitations and Pedagogical Implications}

The conclusion of this research is limited to the participants and setting. The participants who participated to this research were only the first grade English majors of Ufuk University, which is a Foundation University in Ankara, Turkey. It must be noted that the participants formed up a heterogeneous group whose University Entrance Exam Scores were lower that the first 150,000. That's why the mean score of the pretest was $23 \%$ while posttest came up to be $59 \%$. 
I must confessed that I noticed a great deal of negligence, irresponsibility, and laziness in the students both during the course of this research and the during the whole 2017 Fall Term. They didn't seem to care for the Advanced Reading and Writing Course. My other colleagues told me that they behaved the same in their courses. A great deal of them had a tendency to pass of the courses only, no matter what their score is. Moreover, they wait till the last time limit to pass of the courses.

\section{Recommendations}

Learning how to write impactful sentences is an important skill that takes practice that requires discrimination of four types of sentences because sentence structure is a central aspect of every sentence. Once the learners are aware of the different types of sentences and their constructional parts, they can then choose the most helpful type of sentences for the expression of their ideas and can grow them into paragraphs, compositions, and essays by correctly punctuate them. Moreover, understanding of possible problems with sentence such as run-on sentences, fused sentences and comma splices, loose sentences, choppy sentences, and the like are highly essential. Students can appropriately express themselves more clearly in writing when they master how to identify and write the four basic types of sentences along with to placement of appropriate punctuation intra-sententially and word-finally, which make the ideas they are expressing in their writing better understood by the reader.

\section{References}

Alexander, L.G. (2003). Longman English Grammar (20th ed). New York: Longman.

Appelt, D. E. (1992). Planning English sentences. Cambridge: Cambridge University Press.

Bhatia, V.K. (1990). Integrating products, processes, purposes, and participants in professional writing. In C.N. Candlin and K. Hyland (Eds.), Writing: texts, processes, and practices (pp. 2130). London: Longman.

Brandon, L. and Brandon, K. (2010). Sentences, Paragraphs, and Beyond: With Integrated Readings. Wadsworth: Cengage Learning.

Bosher, S. (1998). The composing processes of Southeast Asian writers at the post-secondary level: An exploratory study. Journal of Second Language Writing, 7, 205-240.

Burton-Roberts, N. (2016). Analyzing sentences: An introduction to English Syntax. London: Routledge.

Catts, H.W., Bridges M. S., Little, T.D., and Tomblin, J. B. (2008). Reading achievement growth in children with language impairments. Journal of Speech, Language, and Hearing Research. 2008; 51:1569-1579.

Demirezen, M. (2012). An Analysis of the Problem-Causing Structures of Simple Sentences for Turkish University Students, International Journal of Humanities and Social Science, 2 (3), 135146.

Demirezen, M. (2012a). The Recognition Difficulty of Extended Compound Sentences for Turkish First Year English Language Education Students, 4th World Conference on Educational Sciences University of Barcelona, BARCELONA-SPAIN, 02-05 February, 2012. 
Demirezen, M. (2013). The recognition of extended simple sentences as a teaching writing problem, Procedia - Social and Behavioral Sciences 70 (2013), 560-566. doi: 10.1016/j.sbspro.2013.01.093

Gillam, S. L., Fargo, J.D., Robertson, K. S. (2009). Comprehension of expository text: Insights gained from think aloud data. American Journal of Speech Language Pathology, 18, 82- 94.

Greenbaum, S. and Nelson, G. (2002). An introduction to English Grammar. Pearson Education limited.

Güneş, S. (2013). An analysis of recognition of extended compound sentences. International Online Journal of Education and Teaching (IOJET), 1(1). 25-37. http://iojet.org/index.php/IOJET/article/view/42/61.

Johns, A.M. (1990). L1 composition theories: Implications for developing theories of L2 composition. In B. Kroll (Ed). Second language writing: Research insight for the classroom (pp. 24-36). New York: Cambridge University Press.

Leki, I., \& Carson J.G. (1994). Students' perceptions of EAP writing instruction and writing needs across the disciplines. TESOL Quarterly, 28, 81-101.

Radford, A. (2008). Analyzing English sentences: A minimalist approach. Cambridge: Cambridge University Press.

Samanc1, E. S. (2011). Teaching simple and compound sentences with computers at intermediate level. Dil Dergisi, 154, 7-19.

Scott, C. M. and, Balthazar, C. (2015). The role of complex sentence knowledge in children with reading and writing difficulties. Perspectives on Language and Literacy, 39(3): 18-30.

Scott, C. and Balthazar C. (2010). The grammar of information. Topics in Language Disorders, 30(4), $288-307$.

Verspoor, M. \& Sauter, K. (2000). English Sentence Analysis: An Introductory Course. Amsterdam: John Benjamins Publishing Co.

https://www.youtube.com/watch?v=urr55rAreWc

https://www.youtube.com/watch?v=IuDSRs_lZBk

https://www.youtube.com/watch?v=hWmKnrtlTHU

https://www.youtube.com/watch?v=OR-VsLGytk4

\section{Appendix A.}

\section{IDENTIFY THE TYPES OF TYPES OF SENTENCES IN THE FOLLOWING EXAMPLES?}

1. It took Carlson only eight years to reach the pinnacle of his profession.
a) adverb clause
b) compound sentence
c) complex sentence
d) compound-complex sentence
e) simple sentence

2. A year after the accident, she's finally starting to pull herself together.
a) adjective clause
b) compound sentence
c) simple sentence
d) compound-complex sentence e) complex sentence

3. Regarding your recent inquiry, I've enclosed a copy of our new brochure.
a) compound sentence
b) simple sentence
c) complex sentence
d) compound-complex sentence
e) adjective clause 
4. Depression exists on a continuum, with mild sadness at one end to suicide at the other.
a) simple sentence
b) compound sentence
c) complex sentence
d) complex-complex sentence
e) adverb clause

5. Brett marched out of the office, slamming the door behind him.
a) Noun clause
b) compound sentence
c) complex sentence
d) simple sentence
e) compound-complex sentence

6. We sent thousands of forms, yet fewer than 50 were returned.
a) Adverb clause
b) compound sentence
c) complex sentence
d) simple sentence
e) complex-complex sentence

7. I have paid all of the dues; as a result, I expect to receive all the privileges listed in the by laws
a) Adjective clause
b) complex sentence
c) compound sentence
d) compound-complex sentence
e) simple sentence

8. She did a nursing degree and she did really well, but she's decided to study medicine now
a) Noun clause
b) compound sentence
c) complex sentence
d) simple sentence
e) complex-complex sentence

9. I only made a few more copies, and I didn't think it was any big deal, but he blew up at me!
a) adjective clause
b) complex sentence
c) simple sentence
d) compound-complex sentence
e) compound sentence

10. The forehead is wrinkled, the eyes are puffy, the sacks under the eyes are dark, and the skin is no longer resilient.
a) compound-complex sentence
b) simple sentence
c) complex sentence
d) compound sentence
e) adjective clause

11. As soon as I find it, I'll bring it over to your place.
a) complex sentence
b) Adjective clause
c) compound sentence
d) compound-complex sentence
e) simple sentence

12. Harry flipped out when he found out that I wrecked his motorcycle.
a) Adverb clause
b) complex sentence
c) simple sentence
d) compound-complex sentence
e) compound sentence

13. I heard that sometimes a bad snore can cause heart failure because not enough oxygen gets to the brain.
a) Adverb clause
b) compound sentence
c) complex sentence
d) simple sentence
e) complex-complex sentence

14. It is a Turkish custom that you take off your shoes when you enter a house.
a) compound sentence
b) simple sentence
c) adjective clause
d) compound-complex sentence
e) complex sentence

15. It's hardly surprising that she won't answer his calls after the way he's treated her.
a) complex sentence
b) Adjective clause
c) compound sentence
d) compound-complex sentence
e) simple sentence

16. That man asked me who I was, but I didn't think it was necessary to answer that question
a) simple sentence
b) compound sentence
c) complex sentence

$\begin{array}{ll}\text { d) compound-complex sentence } & \text { e) Noun clause }\end{array}$ 
17. The sun is shining through the clouds, so I think that we can go swimming.
a) adverb phrase
b) compound sentence
c) complex sentence
d) compound-complex sentence
e) simple sentence

18. Rambo expects to win the fight but no one else thinks he can pull it off.
a) compound-complex sentence
b) compound sentence
c) complex sentence

d) adverb phrase

e) simple sentence

19. He says that he saw nothing; however, I don't believe what he says is the truth.
a) simple sentence
b) compound sentence
c) complex sentence
d) adverb phrase
e) compound-complex sentence

20. The man believed in the system, and he knew that justice would prevail after the murderer was sent to jail.
a) Noun clause
b) compound sentence
c) compound-complex sentence
d) simple sentence
e) complex sentence

\section{Öğretmen eğitiminde yazma becerisi için cümle türlerinin belirlenmesi}

\section{$\ddot{O} \mathbf{z}$}

$\mathrm{Bu}$ araştırma, İngiliz ana dallarının dört temel cümle tipini tanımlama yeteneğini araştırmayı amaçlamaktadır. İngilizce dili, farklı türde mesajlar için her tür cümle olmak üzere dört tür cümleye sahiptir. Cümleler, tam düşünceleri ifade eden kelimelerin kombinasyonlarıdır. Cümleler, yazı ve iletişimin temel yapı taşlarıdır; bu nedenle, fikirlerimizi cümle haline getirmek, açık iletişim için şarttır. Geleneksel dilbilgisinde, dört temel cümle yapısı türü, basit cümle, bileşik cümle, karmaşık cümle ve İngiliz olmayan İngilizce öğretmenleri tarafindan özdeşleştirilmesi problemli olabilen bileşik-karmaşı cümledir. İngilizce öğretmenlerinin akademik yazma becerilerini geliştirmek için İngilizce kelime düzenini ve cümle türlerini tanıması çok önemlidir ve dolayısıyla İngilizce öğretmenliğine ilişkin okullarda eğitim görenler için dört tür cümlenin tanımlanması zorunludur. Bu araştırmada, 35 İngilizce öğretmenliği öğrencilerine, ilk başarılarını en başa çıkarmak için çoktan seçmeli bir test olarak 20 soruluk ön test verildi. 6 saatlik yoğun cümle yapısı tanıma çalışmalarından sonra, 15 günlük bir süre sonra aynı ön test verildi, sonuncusu her birinden basit, bileşik, karmaşık cümleler ve bileşik-karmaşık cümle ayrımına ilişkin son başarılarını belirlendi. Ön test ve son testlerden elde edilen verilerin toplanmasından sonra, veriler SPSS 21 ile analiz edilmiştir. Ön testte başarı oranı \%23'ü iken, Son testte başarı oranı \%56 olduğu bulunmuştur, yani çıkış yüzdesi\%23'tür.

Anahtar sözcükler: Karmaşık cümle; bileşik cümle; bileşik-karmaşı cümleler; basit cümle

\section{AUTHOR BIODATA}

Prof. Dr. Mehmet Demirezen is a full professor of linguistics and English Language Education since 1988. His research interests include educational and applied phonetics and phonology, teaching pronunciation and intonation, teaching advanced writing, language acquisition, developing foreign language policies, and bilingualism. He is a teacher educator and also an ELT consultant. Presently, he is serving as the head of the Department of English Education, the Chair of the Division of Foreign Language Teaching and head of the Division of Foreign Languages at Ufuk University, Ankara, Turkey. 